\title{
Assessment of heavy metals bioaccumulation and health risk in crops grown in farmlands around mining sites in Gwana, Alkaleri lga, Bauchi state, Nigeria
}

\author{
Siman Mikin ${ }^{1}$ *, Mohammed Abdullahi Shibdawa ${ }^{1}$, Harami Malgwi Adamu ${ }^{1}$ \\ ${ }^{1}$ Department of Chemistry, Faculty of Science, Abubakar Tafawa Balewa University, Bauchi; Nigeria \\ *Corresponding author E-mail: simanmikin@gmail.com
}

\begin{abstract}
Analysis was carried out on farm crops (Guinea corn, Millet and Beans) collected from adjourning farmlands around mining area of Gwana in Alkaleri Local Government Area, Bauchi State. Their heavy metal concentrations were determined and quantified using Atomic Absorption Spectroscopy (AAS). The heavy metal characterization revealed the presences copper, iron, lead, manganese, nickel and zinc in the farm crops. The mean values of the elements that where obtain for copper, iron, lead, manganese, nickel, silver and zinc by AAS are $33.90,12.00,71.43,12.56,4.40,0.60$ and $101.96 \mathrm{mg} / \mathrm{kg}$, respectively. From the Analysis of variance (ANOVA) used to compare these levels of heavy metals in the crops, it showed that there was a significant difference in their concentration. Exposure assessment and risk characterization of the heavy metals present in the farm crops showed that the mean values of the bioaccumulation coefficient for the elements of copper, iron, lead, manganese, nickel, silver and zinc are1.24, 0.03, 1.68, 0.80,1.64, 0.89 and 1.21 respectively. The estimated daily intake rate for the elements of copper, iron, lead, manganese, nickel and zinc are 1.17 to $1.28 \mathrm{mg} / \mathrm{kg}, 0.03$ to $0.04 \mathrm{mg} / \mathrm{kg}$, 0.06 to $0.011 \mathrm{mg} / \mathrm{kg}, 1.39$ to $1.96 \mathrm{mg} / \mathrm{kg}, 1.92$ to $3.14 \mathrm{mg} / \mathrm{kg}$ and 1.18 to $1.26 \mathrm{mg} / \mathrm{kg}$ respectively. The hazard quotient for the elements of copper, iron, lead, manganese, nickel and zinc are $0.57-1.31,0.01-0.02,22.95-32.50,0.07-0.12,0.02-0.26$ and $0.32-0.40$ respectively. The carcinogenic risk for the elements of lead and nickel are 0.0003-0.0011 and 0.0006-0.0089 respectively. It is hereby recommended that the farm crop samples from within the catchment areas understudy should be subjected to clinical trials to evaluate the extent of the damage it can cause on body tissues.
\end{abstract}

Keywords: Bauchi; Bioaccumulation; Heavy Metals;Hazard Quotient; Mining Sites.

\section{Introduction}

Mining of solid minerals has been identified as a major entry point of heavy metals into the environment consequently polluting its various components such as soil, water and air (Tsafe et al., 2012). In the soil these heavy metals are either accumulated within its matrix, or where they are liable, are transferred amongst its various strata, until they are taken up by plants. Once in these plants, they climb up the food chain posing serious health risk to living organisms (Idzelis et al., 2004). With their detecting in farm lands and plants, heavy metal pollution in the soil is probably one of the foremost ecological problems in the whole world (Claus et al., 2007), especially from the perspective of the serious ecological and human health problems they pose. (Zheljazkov et al., 2006). It is an established fact that majority of these heavy metals are highly hazardous to human health either being carcinogenic, mutagenic, teratogenic, gonadotoxical, embryotoxical or nephrotoxical (Wu et al., 2006).

Owing to the fact that land is a scare resources, there is a worrisome trend of putting reclaimed lands within the vicinity abandoned mining sites to agricultural use thereby increasing the level of bioaccumulation of the heavy metals by the plants and Hazard Risk by the end consumers. In Gwana, Alkaleri local government area, Bauchi state is also known for mining. Therefore, there is a need to assess the level of these contaminants as well as the health risk within the area. There seemed to be a problem of environmental alteration, ecosystem and agricultural land destruction which prompted the researcher to investigate the depth of these environmental impacts.

\section{Materials and methods}

The sample area was around the mining area of Gwana District area, Alkaleri Local Government Area, Bauchi State, Nigeria located 74 $\mathrm{km}$ East of Bauchi town at latitude $9.8653458 \mathrm{~N}$ and longitude $10.8802486 \mathrm{E}$. All the reagents were of analytical grade and were used as purchased. The crop samples were collected by the random sampling method from farmland adjourning the mining area. The samples were then pulverized and passed through a $2 \mathrm{~mm}$ size sieve. The homogenized crop samples were stored in clean and dry containers subsequent to their digestion. $1 \mathrm{~g}$ of the sample was digested using the triacid mixture of concentrated nitric acid $\left(\mathrm{HNO}_{3}\right)$, sulphuric acid $\left(\mathrm{H}_{2} \mathrm{SO}_{4}\right)$ and perchloric acid $\left(\mathrm{HClO}_{4}\right)$ in 5:1:1 ratio as described by Ademorati, 1996). The heavy metal concentrations in the digest were determined at 
the Center for Energy Research and Development, Abubakar Tafawa Balewa University Bauchi, using the Atomic Absorption Spectrophotometer.

\subsection{Data analysis}

The Bioaccumulation Coefficient of heavy metals in some selected farm crops collected from adjourning farm lands in Alkaleri Local Government Area of Bauchi State where deduced using the equation below:

Bioaccumulation Coefficient $=\frac{\text { Mean Metal concentration }(\mathrm{mg} / \mathrm{Kg}) \text { in grains }}{\text { Mean Metal concentration }(\mathrm{mg} / \mathrm{Kg}) \text { in soil }}$

The heavy metals estimated daily intake (EDI) was dependent on the heavy metals level in grains of food crops obtained from farms adjourning the mining areas. The metals EDI was calculated using the following equation:

$\operatorname{EDIR}=\frac{\mathrm{M}_{\mathrm{C}} \times \mathrm{IR}}{\mathrm{BW}}$

Where, $M_{c}$ is the metal concentration in the farm crops ( $\mathrm{mg} / \mathrm{kg}$ dry weight). IR is the ingestion rate, which is obtained from an oral questionnaire applied on the spot and the consumption rate arrived at are $100 \mathrm{~g}$ of Guinea corn as pap, $100 \mathrm{~g}$ of Millet as pap and 50g of beans as bean cake. The assumption of an adult ingestion rate of grains over a lifetime is a high estimate of actual grains consumption. BW is average body weight was taken as $70 \mathrm{~kg}$ (WHO, 1993). Then compared to the metals Tolerable Daily Intakes (TDIs).

The hazard quotient (HQ) of the individual metals present in the farm crops were calculated to assess the health risk they pose to human consuming. HQ is a dimensionless estimate of the non-carcinogenic risk level due to heavy metal exposure through the food chain and was calculated based on the following equation (Yi et al., 2011):

$\mathrm{HQ}=\frac{\mathrm{M}_{\mathrm{c}} \times \mathrm{IR} \times \mathrm{EF} \times \mathrm{ED}}{\operatorname{RfD} \times \mathrm{BW} \times \mathrm{T}_{\mathrm{n}}}$

$\mathrm{EF}$ is the exposure frequency (365 days/year). ED is the exposure duration (70 years). RfD is the reference dose of individual metal (mg/kg/ day), $\mathrm{Cu}=0.04, \mathrm{Fe}=0.7, \mathrm{Mn}=0.14, \mathrm{Ni}=0.02, \mathrm{~Pb}=0.004, \mathrm{Zn}=0.3$ (USEPA, 2012). ATn is the averaging time for non-carcinogens $(365$ days/year $\times$ ED) $($ USEPA, 2011).

The sum of the overall potential health risk posed by all the metals present in the farm crops is known as hazard index (HI) and is calculated by the summation of the hazard quotients of every metal present in each food item (USEPA, 2011).

$\mathrm{HI}=\mathrm{HQCu}+\mathrm{HQFe}+\mathrm{HQMn}+\mathrm{HQNi}+\mathrm{HQPb}+\mathrm{HQZn}$

Carcinogenic Risk (CR) for carcinogen, is determined as a multiple of the estimated daily dose and the Cancer Slope Factor (CSF). CSFs are estimates of carcinogenic potency and are used to relate estimate daily dose of a substance over a lifetime exposure to the lifetime probability of excess tumors. The Ingestion CSFs evaluate the probability of an individual developing cancer from oral exposure to contaminants levels over a lifetime. Ingestion CSFs are expressed in units of $\mathrm{mg} / \mathrm{kg} /$ day. Lifetime probability of contracting cancer due to exposure to carcinogenic chemicals is calculated as follows:

$\mathrm{CR}=\mathrm{EDIR} \times \mathrm{CSF}_{\text {Ing }}$

Where, $\mathrm{CR}=$ Carcinogenic Risk; EDIR=Estimated Daily Intake Rate of each heavy metal ( $\mathrm{mg} / \mathrm{kg} / \mathrm{day})$; $\mathrm{CSF}$ ing= Cancer Slope Factor from Ingestion (mg/kg/day) $\mathrm{Ni}=1.7, \mathrm{~Pb}=0.0085$ (USEPA, 2011). CSF for $\mathrm{Mn}, \mathrm{Fe}, \mathrm{Co}, \mathrm{Cu}$ and $\mathrm{Zn}$ are yet to be established, hence are not considered to have any carcinogenic effect (USEPA 2012). There are certain assumptions which should be taken while evaluating the HQ for human health risk which are: ingested dose of pollutant is equal to the absorbed dose (USEPA 1989) and cooking has no effect on pollutants (Forti et al. 2011).

\section{Results and discussion}

The heavy metal composition in the crops which were collected from farmland adjourning mining sites, where mining activities was being carried out in Gwana, Alkaleri Local Government Area of Bauchi State revealed the presence of the following arsenic, cadmium, chromium, cobalt, copper, iron, lead, manganese, nickel and zinc. The heavy metal composition and their corresponding concentrations in the farm produce are presented in Table 1 below.

Table 1: Heavy Metal Composition and Their Concentrations in Farm Crops Taken From Locations Associated with Mining Activities Around Gwana, Alkaleri Local Government Area of Bauchi State

\begin{tabular}{llll}
\hline & Guinea corn $(\mathrm{mg} / \mathrm{Kg})$ & Millet $(\mathrm{mg} / \mathrm{Kg})$ & Beans $(\mathrm{mg} / \mathrm{Kg})$ \\
\hline $\mathrm{Ag}$ & $0.6 \pm 0.00$ & $0.5 \pm 0.00$ & $0.1 \pm 0.01$ \\
$\mathrm{Cd}$ & $\mathrm{BDL}$ & BDL & BDL \\
$\mathrm{Co}$ & $\mathrm{BDL}$ & BDL & BDL \\
$\mathrm{Cr}$ & $\mathrm{BDL}$ & BDL & BDL \\
$\mathrm{Cu}$ & $36.7 \pm 0.13$ & $32.8 \pm 0.18$ & $32.2 \pm 0.02$ \\
$\mathrm{Fe}$ & $11.0 \pm 0.04$ & $11.0 \pm 0.04$ & $14.0 \pm 0.12$ \\
$\mathrm{Mn}$ & $12.1 \pm 0.00$ & $9.5 \pm 0.00$ & $16.1 \pm 0.01$ \\
$\mathrm{Ni}$ & $3.7 \pm 0.00$ & $4.3 \pm 0.00$ & $5.3 \pm 0.00$ \\
$\mathrm{~Pb}$ & $91.6 \pm 0.03$ & $64.3 \pm 0.00$ & $58.4 \pm 0.04$ \\
$\mathrm{Zn}$ & $83.6 \pm 0.32$ & $86.4 \pm 0.14$ & $135.9 \pm 0.06$ \\
\hline $\mathrm{Vat}$ & & & \\
\hline
\end{tabular}

Values are mean \pm standard deviation $(n=3)$.

$\mathrm{BDL}=$ Below Detection Level. 
Statistical analysis of the levels of the analyzed heavy metals in the food crops obtained from the adjourning farmland showed significant differences $(\mathrm{p}<0.05)$ in levels of $\mathrm{Ag}, \mathrm{Cr}, \mathrm{Cu}, \mathrm{Fe}, \mathrm{Mn}, \mathrm{Ni}, \mathrm{Pb}$ and $\mathrm{Zn}$. Among all the heavy metals, $\mathrm{Pb}$ concentration was the highest and $\mathrm{Fe}$ was the least in all the farm crops.

\subsection{Bioaccumulation coefficient}

Biological Accumulation Coefficient were calculated to highlight the availability of the metal ions and their uptake by a particular farm produce, since it has been observed the total concentration of heavy metal in a soil does not actually portray its availability for plant uptake (Brooks et al, 1977). Going by the results obtained by the AAS methods, there was no detection of Cadmium, Chromium, and Cobalt. (Adamu et al., 2011).

Table 2: Bioaccumulation Coefficient of Heavy Metals in Some Selected Farm Crops Collected from Adorning Farm Lands in Alkaleri Local Government Area of Bauchi State

\begin{tabular}{llll} 
& Guinea corn & Millet & Beans \\
\hline $\mathrm{Cu}$ & 1.17 & 1.28 & 1.27 \\
$\mathrm{Fe}$ & 0.03 & 0.03 & 0.04 \\
$\mathrm{Co}$ & - & - & 0.11 \\
$\mathrm{Mn}$ & 0.08 & 0.06 & 1.96 \\
$\mathrm{Ni}$ & 1.37 & 1.59 & 1.92 \\
$\mathrm{~Pb}$ & 3.14 & - & - \\
$\mathrm{Cr}$ & - & - & 1.21 \\
$\mathrm{Zn}$ & 1.26 & 1.18 & 1.05 \\
$\mathrm{Ag}$ & 0.84 & 0.78 & - \\
$\mathrm{Cd}$ & - & - & \\
\hline
\end{tabular}

The general trend in bioaccumulation coefficient of the heavy metals in Guinea corn was Lead $>$ Nickel $>$ Zinc $>$ Copper $>$ Silver $>$ Manganese > Iron, for millet the trend in bioaccumulation coefficient of the heavy metals was Nickel $>$ Copper $>$ Zinc $>$ Silver $>$ Manganese $>$ Iron and for beans the trend of it bioaccumulation coefficient of the heavy metals was Lead $>$ Nickel $>$ Copper $>$ Zinc $>$ Silver $>$ Manganese > Iron.

Of the aforementioned heavy metals, lead was observed to have the highest bioaccumulation of 3.14 in guinea corn and 1.96 in beans respectively. Followed by nickel in all the food produce: 1.37 in guinea corn, 1.59 in millet and 1.96 in beans. Iron had the least bio accumulation in all the farm produce 0.03 in guinea corn, 0.03 in millet and 0.04 in beans. While the bioaccumulation of heavy metals like cobalt, chromium and cadmium in the farm produce was totally absent, which conforms to similar findings by Prince et al. (2001) who noted that heavy metals such as $\mathrm{Cd}$, Co and Cd were usually present in low concentrations in plant component.

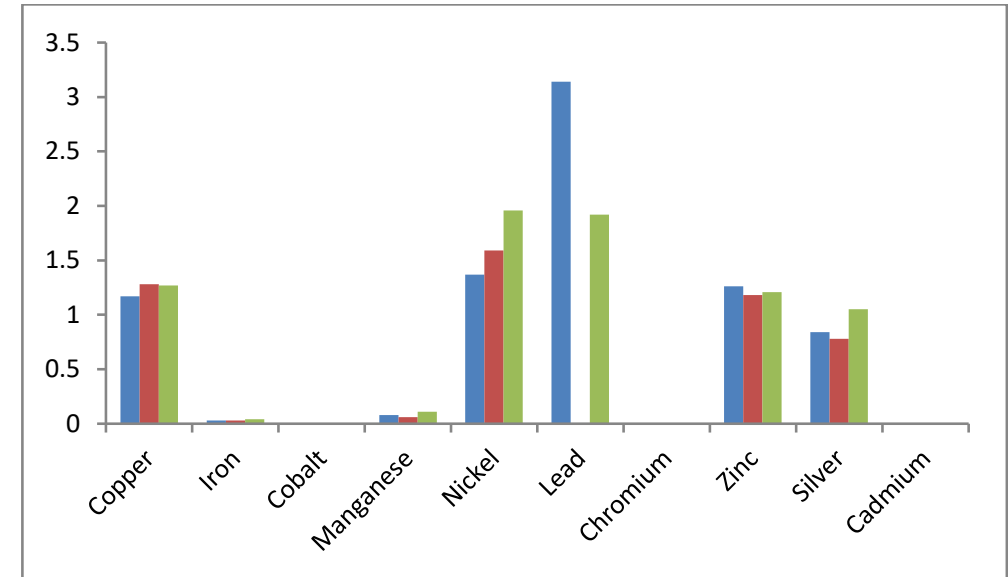

Fig. 1: Biological Accumulation Coefficient of Metals in Farm Produce Adjourning Farmland at Mining Sites in Gwana, Alkaleri.

In all the farm crops, except for Millet Lead bioaccumulation was observed to be higher compared to Iron and Manganese which are compared to be essential micronutrients both for plant growth and human consumption. The low bio accumulation of iron in the crops, when compared with the report made by Nivethitha et al., 2002 and Nirmal et al., 2007 could suggest that the soil is to iron deficient.

\subsection{Human exposure and risk assessment of the heavy metals present in some selected farm crops collected from adjourning farm lands in alkaleri local government area of bauchi state}

Exposure assessment and risk characterization of the heavy metals present in some selected farm crops collected from adjourning farm lands in Alkaleri Local Government Area of Bauchi State

of the local population living in that surroundings were evaluated using Daily Intake Rate, Hazard Index and Carcinogenic Risk methodology. Usually, exposure of humans to heavy metals in industry contaminated soils can occur via three main pathways which are oral ingestion, dermal contact, and inhalation of soil particles. The oral ingestion routes of exposure were considered when evaluating the carcinogenic effects and hazard index of the heavy metals present in the food items obtained from the adjourning farm land.

\subsection{Estimated daily intake rate (EDI)}

The EDI of heavy metals by the exposed population is presented in Figure 2. The calculated EDI for copper ranged between 0.0230 to $0.0524 \mathrm{mg} / \mathrm{kg} / \mathrm{day}$, with the highest EDI level recorded in guinea corn $(0.0524 \mathrm{mg} / \mathrm{kg} / \mathrm{day})$, while the lowest level of calculated EDI was recorded in guinea corn $(0.0230 \mathrm{mg} / \mathrm{kg} / \mathrm{day})$. For iron ranged between 0.0100 to $0.0157 \mathrm{mg} / \mathrm{kg} / \mathrm{day}$, with the highest EDI level recorded in 
guinea corn and millet $(0.0157 \mathrm{mg} / \mathrm{kg} /$ day $)$, while the lowest level of calculated EDI was recorded in beans $(0.0100 \mathrm{mg} / \mathrm{kg} / \mathrm{day})$. For manganese ranged between 0.0107 to $0.0172 \mathrm{mg} / \mathrm{kg} / \mathrm{day}$, with the highest EDI level recorded in millet $(0.0172 \mathrm{mg} / \mathrm{kg} / \mathrm{day})$, while the lowest level of calculated EDI was recorded in beans $(0.0107 \mathrm{mg} / \mathrm{kg} / \mathrm{day})$.

Table 3: Estimated Daily Intake (EDI) of Heavy Metals in Some Selected Farm Crops Collected from Adjourning Farm Lands in Alkaleri Local Government Area of Bauchi State

\begin{tabular}{llll}
\hline & Guinea corn $(\mathrm{mg} / \mathrm{kg} /$ day $)$ & Millet $(\mathrm{mg} / \mathrm{kg} / \mathrm{day})$ & $\mathrm{Beans}(\mathrm{mg} / \mathrm{kg} / \mathrm{day})$ \\
\hline $\mathrm{Ag}$ & 0.0008 & 0.0001 & 0.0001 \\
$\mathrm{Cu}$ & 0.0524 & 0.0468 & 0.0230 \\
$\mathrm{Fe}$ & 0.0157 & 0.0157 & 0.0100 \\
$\mathrm{Mn}$ & 0.0172 & 0.0135 & 0.0107 \\
$\mathrm{Ni}$ & 0.0052 & 0.0042 & 0.0003 \\
$\mathrm{~Pb}$ & 0.1300 & 0.0918 & 0.0417 \\
$\mathrm{Zn}$ & 0.1190 & 0.1228 & 0.0970 \\
\hline
\end{tabular}

For nickel ranged between 0.0003 to $1.96 \mathrm{mg} / \mathrm{kg} / \mathrm{day}$, with the highest EDI level recorded in guinea corn $(0.0052 \mathrm{mg} / \mathrm{kg} / \mathrm{day})$, while the lowest level of calculated EDI was recorded in beans $(0.0003 \mathrm{mg} / \mathrm{kg} / \mathrm{day})$. For lead ranged between 0.0417 to $0.1300 \mathrm{mg} / \mathrm{kg} / \mathrm{day}$, with the highest EDI level recorded in guinea corn $(0.1300 \mathrm{mg} / \mathrm{kg} /$ day $)$, while the lowest level of calculated EDI was recorded in beans $(0.0417 \mathrm{mg} / \mathrm{kg} / \mathrm{day})$. For zinc ranged between 0.0970 to $0.1228 \mathrm{mg} / \mathrm{kg} / \mathrm{day}$, with the highest EDI level recorded in millet $(0.1228$ $\mathrm{mg} / \mathrm{kg} /$ day $)$, while the lowest level of calculated EDI was recorded in beans $(0.0970 \mathrm{mg} / \mathrm{kg} /$ day $)$.

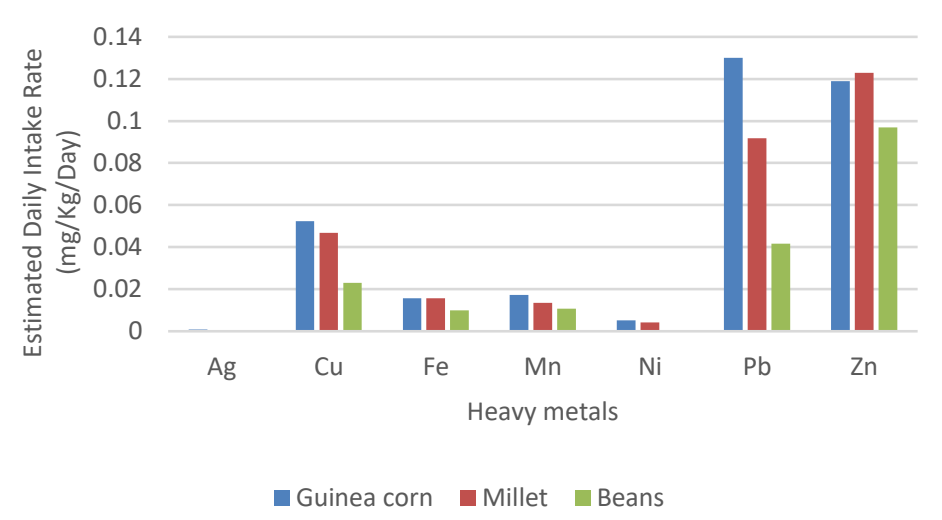

Fig. 2: Estimated Daily Intake Rate (EDIR) of the Heavy Metals Present in Some Selected Farm Crops Collected from Adjourning Farm Lands in Alkaleri Local Government Area of Bauchi State.

The EDI result presented in Figure 2 when compared with the recommended tolerable daily intake of metals (TDI) showed that they were within the limits specified by the Institute of medicine (FDA, 2001)

\subsection{Hazard quotient (HQ) and hazard index}

The Hazard Index of the heavy metals present in some selected farm crops collected from adjourning farm lands in Gwana, Alkaleri LGA, Bauchi State are presented in Table 4. It is noted that, where the Hazard Index exceeds 1.0, it is likely that there will be adverse effects to human health.

Table 4: Hazard Quotient and Hazard Index (HI) of Heavy Metals in Some Selected Farm Crops Collected from Adjourning Farm Lands in Alkaleri Local Government Area of Bauchi State

\begin{tabular}{llll} 
& & \\
& Hazard Quotient & Millet & \\
\hline $\mathrm{Cu}$ & Guinea corn & 1.17 & 0.02 \\
$\mathrm{Fe}$ & 1.31 & 0.02 & 0.01 \\
$\mathrm{Mn}$ & 0.02 & 0.09 & 0.07 \\
$\mathrm{Ni}$ & 0.12 & 0.21 & 0.02 \\
$\mathrm{~Pb}$ & 0.26 & 22.95 & 24.26 \\
$\mathrm{Zn}$ & 32.50 & 0.40 & 0.32 \\
$\mathrm{Hazard}$ Index & 0.39 & 24.85 & 25.25 \\
\hline
\end{tabular}

The Human Exposure Assessment Hazard Quotient was employed as indicators of whether the levels of heavy metals contained in some selected farm crops collected from adjourning farm lands in Gwana, Alkaleri LGA, Bauchi State would pose any health risk to the consumers resident within the environs. The values obtained for the Hazard Quotient (HQ) of copper, iron, lead, manganese, nickel and zinc are presented in Figure 3.

In Figure 3, it shows that the Hazard Quotient for copper was between 0.57-1.31 (0.57 in beans, 1.17 in Millet and 1.31 in guinea corn), iron was between $0.01-0.02$ ( 0.1 in beans and 0.2 in millet and guinea corn respectively), lead was between $22.95-32.50$ (22.95 in millet, 24.26 in beans and 32.5 guinea corn), manganese was between $0.07-0.12$ (0.07 in beans, 0.09 in millet and 0.12 in guinea corn), nickel was between $0.02-0.26$ ( 0.02 in beans, 0.21 in millet and 0.26 in guinea corn) and zinc was between $0.32-0.40$ ( 0.32 in beans, 0.39 in guinea corn and 0.4 in millet), all observed to be below 1 except for copper and lead. Being an indication that their levels as present in the farm crops collected from farm lands around mining area in Gwana, Alkaleri Local Government Area of Bauchi State poses no health risk to the consumers within the environs. The Hazard Quotient index recorded was for lead with an index of 32.5 in guinea corn and the least was those of nickel with an index of 0.022 beans. Individually, it was observed that, guinea corn had the highest Hazard Quotient among the food items that were assessed, while beans had the least in all the crops under study. 


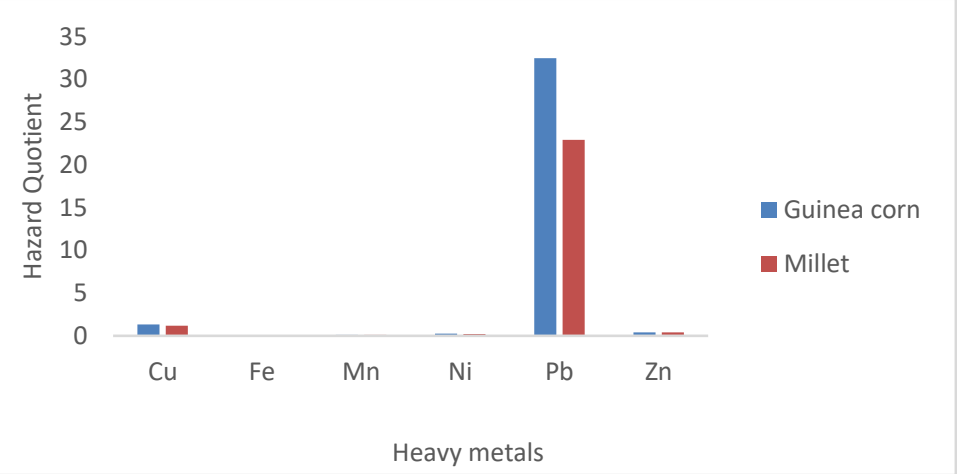

Fig. 3: Hazard Quotient of the Heavy Metals Present in Some Selected Farm Crops Collected from Adjourning Farm Lands in Gwana, Alkaleri Local Government Area of Bauchi State.

The Hazard Quotient where so far higher than those reported by Morshdy et al, (2018) for $\mathrm{Pb}, \mathrm{Zn}$ and $\mathrm{Cu}$ which ranged from 0.00006 to $0.14115,0.00002$ to 0.01403 and 0.000057 to 0.057972 , respectively, for various muscles and organs of camel, cattle, buffalo and sheep that were analyzed. However, in a study undertaken by Guerra et al., (2012), it was reported that the hazard quotient for $\mathrm{Ni}, \mathrm{Pb}$ and $\mathrm{Cu}$ ranged from 0 to 0.0107 ; from 0 to 0.0701 and from 0 to 0.0045 which were either slightly above the range reported in this study or within the range. When the hazard index exceeds 1.0, there is concern for potential health effects (Huang et al., 2008). Even though there was no apparent risk when each metal was analyzed individually, the potential risk could be multiplied when considering all heavy metals.

\subsection{Carcinogenic risk (CR)}

The Carcinogenic Risk of the heavy metals present in some selected farm crops collected from adjourning farm lands in Alkaleri Local Government Area of Bauchi State are presented in Table 5.

Table 5: Carcinogenic Risk of Heavy Metals in Some Selected Farm Crops Collected from Adorning Farm Lands in Gwana Alkaleri Local Government Area of Bauchi State

\begin{tabular}{llll}
\hline & Guinea corn & Millet & Beans \\
\hline $\mathrm{Ni}$ & 0.0089 & 0.0072 & 0.0006 \\
$\mathrm{~Pb}$ & 0.0011 & 0.0007 & 0.0003 \\
\hline
\end{tabular}

The human Exposure assessment of the Carcinogenic Risk presented in Figure 4, shows that the risk toxicity for lead was between $0.0003-$ 0.0011 (0.0003 in beans, 0.0007 and 0.0011 in guinea corn) and Nickel was between $0.0006-0.0089(0.0006$ in beans, 0.0072 and 0.0089 in guinea corn). these values of Carcinogenic Risk of lead and nickel were observed to be very minimal to pose any health risk. However, it was generally observed that beans had the least carcinogenic risk, followed by millet and guinea corn.

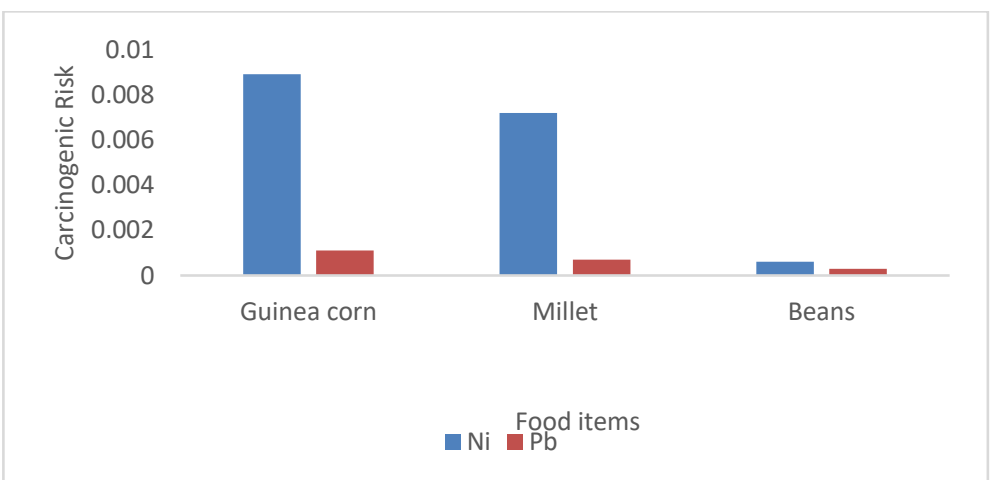

Fig. 4: Carcinogenic Risk of the Heavy Metals Present in Some Selected Farm Crops Collected from Adjourning Farm Lands in Gwana, Alkaleri Local Government Area of Bauchi State.

\section{Conclusions}

The concentration of heavy metals in the farm crops collected from the study area revealed that the Hazard Quotient of lead were excessively high in all the farm crops sampled, distantly followed by coper which was observed to be above the threshold of 1 . Hence the conclusion that there may be case of toxic lead contamination of the farm crops as a result of the mining activities being carried out within the locality. This conclusion is collaborated with the carcinogenic risk index which is also high in the case of lead.

\section{References}

[1] Ademorati CMA (1996). Case studies of bioaccumulation of heavy metals. Environmental chemistry and Toxicology. Foludex press Ltd. Ibadan, Nigeria. pp. 130-136.

[2] Food and Drug Administration, 2001. Dietary Reference Intakes for Vitamin A, Vitamin K, Arsenic, Boron, Chromium, Copper, Iodine, Iron, Manganese, Molybdenum, Nickel, Silicon, Vanadium, and Zinc. Report of the Panel on Micronutrients. National Academy Press, Washington, DC Food and Drug Administration, Dietary supplements, Center for Food Safety and Applied Nutrition.

[3] Guerra, F., Anderson Ricardo Trevizam2, Takashi Muraoka3*, Nericlenes Chaves Marcante4, Solange Guidolin Canniatti-Brazaca (2012) Heavy metals in vegetables and potential risk for human health. Science Agricola 69 (1) 54-60 https://doi.org/10.1590/S0103-90162012000100008. 
[4] Idzelis, R. L., Budreika A, Vaiskunaite R (2004). Dirvozemio tarsos sunkiaisiais metals Kairiu karinio poligono teritorijoje tyrimai ir vertinimas. Journal of Environmental Engineering and Landscape Management. 12(2):42-48.

[5] Morshdy, A. E. M. A., Rasha M. El Bayomi, Ghada M. Abd El Galil, Abdallah F.A. Mahmoud Heavy (2018) metal concentrations and their risk assessment in marketed slaughtered animals in Sharkia Governorate, Egypt Slov Vet Res. 55 (Suppl 20): 103-12

[6] Nirmal Kumar, J. I., Soni, H. and Kumar, R. N. (2007). Characterization of heavy metals from market vegetables using Inductive Coupled Plasma Analyzer (ICPA). International Journal of Biosciences Reporter 5(1):71-76.

[7] Nivethitha, P., Thnagavel, P., Prince, S. P. M. W. and Subburam, V. (2002). Identification of heavy metal accumulating plants and their use in reclamation of soil contaminated with heavy metals. International Journal of Ecology, Environment and Conservation 8(3):249-251.

[8] Prince, S. P. M. W., Senthilkumar, P. and Subburam, V. (2001). Mulberry-Silkworm food chain-A template to assess heavy metal mobility in terrestrial ecosystems. Environmental Monitoring and Assessment 69:231-238 https://doi.org/10.1023/A:1010715606097.

[9] Song, B., Lei, M., Chen, T., Zheng, Y. M., Xie, Y. F., Li, X.Y. and Gao, D. (2009) Assessing the health risk of heavy metals in vegetables to the general population in Beijing, China. Journal Environmental Science (China) 21:1702-1709 https://doi.org/10.1016/S1001-0742(08)62476-6.

[10] Tsafe, A. I., Hassan, L. G., Sahabi, D. M., Alhassan, Y. and Bala, B. M. (2012). Evaluation of Heavy Metals Uptake and Risk Assessment of Vegetables Grown in Yargalma of Northern Nigeria. Journal of Basic and Applied Science Research 2(12):6708-6714.

[11] United State Environmental Protection Agency, (2011). Risk-based concentration table. United State Environmental Protection Agency, Washington, USA.

[12] United States Environmental Protection Agency (1989). Risk Assessment Guidance for Superfund Volume I: Human Health Evaluation Manual (Part A). Washington, DC: US Environmental Protection Agency, Office of Emergency and Remedial

[13] United States Environmental Protection Agency, (2012). Reference dose (RfD): Description and use in health risk assessments, Background Document 1A, Integrated risk information system (IRIS); United States Environmental Protection Agency: Washington, DC,

[14] Wu, S., Peng, S. P., Zhang, X. X., Wu, D. L., Luo, W., Zhang, T. B., Zhou, S. G., Yang, G. Y., Wan, H. F. and Wu, L. Q. (2015) Levels and health risk assessments of heavy metals in urban soils in Dongguan, China. Journal of Geochemical Explorations 148:71-78. https://doi.org/10.1016/j.gexplo.2014.08.009.

[15] Yi Y, Yang Z. and Zhang S. (2011) Ecological risk assessment of heavy metals in sediment and human health risk assessment of heavy metals in fishes in the middle and lower reaches of the Yangtze River basin. Environ Pollut. 159: 2575-85. https://doi.org/10.1016/j.envpol.2011.06.011.

[16] Zheljazkov, V. D., Craker, L. E., Xing, B. (2006). Effect of Cd, Pb, and Cu on growth and essential contents in dill. Peppermint, and basil. Environmental and Experimental Botany. 58(1-3):9-16. https://doi.org/10.1016/j.envexpbot.2005.06.008. 